\title{
KREATIVITAS DAN INOVASI DALAM ISLAM TERHADAP KEBERLANGSUNGAN UMKM DI MASA PANDEMI COVID-19 DI INDONESIA
}

\author{
R. Gatot Heru Pranjoto \\ pranjotogatot@gmail.com \\ Fakultas Ekonomi dan Bisnis, Universitas Trunojoyo Madura
}

\begin{abstract}
ABSTRAK
Usaha mikro kecil dan menengah (UMKM) merupakan sektor riil ketiga dalam pasar output yang bersama-sama menghasilkan value added (diukur dalam GDP) dalam sebuah perekonomian. Akan tetapi di tahun 2020 ini, Indonesia juga mengalami bencana dunia yang disebabkan oleh Covid-19. Penelitian ini bertujuan untuk menjelaskan kreativitas dan inovasi dalam Islam terhadap keberlangsungan UMKM di Indonesia di tengah-tengah merebakakunya Covid19, serta memberikan beberapa kiat-kiat untuk membangun dua aspek tersebut. Dalam penelitian ini diharapkan dapat memberikan informasi dan solusi bagi seluruh masyarakat, terutama umat muslim sebagai penduduk terbanyak di Indonesia dalam mengatasi guncangan ekonomi saat ini. Penelitian ini merupakan penelitian kualitatif deskriptif berbasis data sekunder. Sebelum sesorang mendirikan sebuah bisnis usaha, haruslah mengetahui dan mengenal lingkungan usahanya baik dalam lingkup mikro maupun makro. Kemudian seorang pembisnis harus memiliki link atau hubungan kerjasama yang luas dengan pembisnis lainnya yang berperan sebagai penyalur atau dropsipper. Selanjutnya, seorang pembisnis harus dapat mengamati kondisi ekonomi yang tengah terjadi di masa Pandemi Covid-19 saat ini, Bagi seorang pelaku ekonomi di sektor UMKM, kreativitas dan inovasi memang sangat dibutuhkan. Untuk dapat mengambangkan kedua aspek utama tersebut, Seorang pelaku UMKM harus memiliki kiat-kiat agar dapat bertahan dan mampu bersaing di tengahtengah pandemi Covid-19.

Kata Kunci: Kreativitas dan Inovasi, UMKM, Pandemi Covid-19.
\end{abstract}

\section{ABSTRACT}

Micro, small and medium enterprises (MSMEs) are the third real sector in the output market which together produce value added (measured in GDP) in an economy. However, in 2020, Indonesia is also experiencing a world disaster caused by Covid-19. This study aims to explain creativity and innovation in Islam for the sustainability of MSMEs in Indonesia in the midst of the Covid-19 outbreak, and to provide some tips for building these two aspects. This research is expected to provide information and solutions for the entire community, especially Muslims as the largest population in Indonesia in overcoming the current economic shocks. This research is a descriptive qualitative research based on secondary data. Before someone establishes a business, one must know and be familiar with the business environment both in the micro and macro scope. Then a businessman must have a link or extensive cooperation relationship with other businessmen who act as distributors or droppersons. Furthermore, a businessman must be able to observe the economic conditions that are happening during the current Covid-19 Pandemic. For an economic 
player in the MSME sector, creativity and innovation are really needed. To be able to develop these two main aspects, an MSME actor must have tips so that he can survive and be able to compete in the midst of the Covid-19 pandemic. Keywords: Creativity and Innovation, MSMEs, Covid-19 Pandemic.

\section{PENDAHULUAN}

Di tahun 2020 ini, para pelaku Usaha Mikro, Kecil, dan Menengah (UMKM) telah banyak belajar dalam membaca kebutuhan pasar, tata kelola usaha sesuai dengan manajamen bisnis, dan tidak sedikit yang telah memiliki laporan keungan meskipun dalam bentuk sederhana. Sektor UMKM telah mengalami perkembangan pada sistem pengelolaannya, ini tidak lepas dari keinginan pelaku usahanya yang mau bekembang dalam kreatifitas dan inovasi. Menurut Suryana (2013: 10) Jiwa kewirausahaan ada pada setiap orang yang memiliki kemampuan kreatif dan inovatif, dan pada setiap orang yang menyukai perubahan, pembaruan, kemajuan, dan tantangan. Banyak masyarakat kecil berpengetahuan rendah hingga kaum terpelajar yang melakukan bisnis usaha melalui sektor UMKM, baik bertujuan untuk belajar atau memulai suatu bisnis dan memperoleh pendapatan.

Usaha mikro, kecil, dan menengah (UMKM) merupakan sektor riil ketiga dalam pasar output yang bersama-sama menghasilkan value added (diukur dalam GDP) dalam sebuah perekonomian (Darsono, dkk., 2018: 32). Dalam Undang-Undang Nomor 20 Tahun 2008 Bab II yang berbunyi "usaha mikro kecil dan menegah bertujuan menumbuhkan dan mengembangkan usahanya dalam rangka membangun perekonomian nasional berdasarkan demokrasi ekonomi yang berkeadilan". UMKM merupakan alternatif yang mampu mengurangi beban berat yang dihadapi oleh perekonomian nasional (Helmalia dan Afrinawati, 2018). Menurut David McClelland dalam Astamaoen (2005: 11), suatu negara akan mencapai tingkat kemakmuran dan kesejahteraan apabila jumlah enterpreneur-nya paling sedikit $2 \%$ dari total jumlah penduduknya. Sektor UMKM merupakan solusi terbaik bagi masyarakat kecil karena dapat dijadikan sebagai lapangan pekerjaan dan media dalam memperoleh penghasilan. Hal ini mengurangi angka pengangguran di Indonesia.

Akan tetapi di tahun 2020 ini, Indonesia juga mengalami bencana dunia yang disebabkan oleh Covid-19. Berdasarkan data yang dirilis oleh website.corona.help.com dan website.worddometer.com per 3 April 2020 dalam Taufik dan Eka (2020), menunjukkan bahwa Indonesia berada pada urutan pertama diantara negara-negara 
ASEAN. Tidak sedikit UMKM yang mengalami kerugian karena adanya kebijakan pemerintah guna mencegah penularannya. Beberapa diantaranya adalah tidak diperbolehkannya kontak langsung antara pembeli dan penjual, dan berkumpulnya konsumen dalam jumlah banyak pada satu tempat. Kerugian tersebut akan berdampak langsung bagi pelaku usaha menengah ke bawah sehingga angka pengangguran dapat meningkat kembali. Menteri Koordinator Bidang Perekonomian, Airlangga Hartanto memprediksi, dalam skenario berat potensi pengangguran akan bertambah 2,92 juta orang dan bisa bertambah sangat besar bisa mencapai 5,23 juta (Rohmah, 2020). Menurut Menteri Keuangan, Sri Mulyani Indrawati memprediksi, hal ini juga berdampak pada petumbuhan ekonomi dalam skenario terburuk yag dapat mencapai minus 0,4\% (Aswar, www.kemenkeu.go.id, 4 Mei 2020).

Berdasarkan penjelasan di atas, dalam situasi seperti ini, diperlukan adanya solusi yang tepat agar pelaku UMKM tersebut agar dapat terus menjalankan bisnis usahanya sesuai dengan harapan. Penelitian ini bertujuan untuk menjelaskan kreativitas dan inovasi dalam Islam terhadap keberlangsungan UMKM di Indonesia di tengah-tengah merebakakunya Covid-19, serta memberikan beberapa kiat-kiat untuk membangun dua aspek tersebut. Dalam penelitian ini diharapkan dapat memberikan informasi dan solusi bagi seluruh masyarakat, terutama umat muslim sebagai penduduk terbanyak di Indonesia dalam mengatasi guncangan ekonomi saat ini.

\section{LANDASAN TEORI}

\section{Kreatifitas dan Inovasi dalam Islam}

Usaha Mikro, Kecil, dan Menengah (UMKM) termasuk dalam kewirausahaan (enterpreneurship) dalam lingkup yang lebih kecil atau sederhana. Dari penjelasan latar belakang di atas, dapat diketahui bahwa UMKM sangat mengedepankan kreativitas dan inovasi dalam praktiknya. Menurut Peter F. Drucker dalam Suryana (2013: 10) kewirausahaan melekat pada sifat, watak, dan ciri-ciri seseorang yang berkeinginan keras mewujudkan gagasan inovatif ke dalam dunia usaha yang nyata dan dapat mengembangkannya dengan tangguh. Menurut Zimmerer (1996: 51):

"enterpreneurship is applying creativity and innovation to solve the problems and to exploit opportunities that people face everyday".

Dimana kewirausahaan merupakan sebuah penerapan kreativitas dan inovasi dalam memecahkan masalah dan pemanfaatan peluang yang dihadapi setiap hari. Menurut 
Peggy A. Lambing dan Charles R. Kuehl dalam Hendro dan Chandra (2006: 21) enterpreneurship diartikan sebagai suatu usaha kreatif yang membangun suatu value dari yang belum ada menjadi ada dan bisa dinikmati banyak orang.

Dalam Islam, kreativitas dan inovasi juga berkaitan dengan ketakwaaan pada setiap individu sebaga pelaku ekonomi, mengarahkan pada aktivitas ekonomi yang positif. Ketakwaan kepada Tuhan akan membawa diri seseorang untuk lebih produktif (Pusat Pengkajian dan Pengembangan Ekonomi Islam, 2014: 14). Hal ini sesuai dengan usaha manusia dalam mengalokasikan dan mengelola sumber daya yang bertujuan untuk mencapai falah (kesuksesan) berdasarkan pada prinsip-prinsip dan nilai-nilai al-Qur'an dan Sunnah.

Tabel 1. Aspek mikro dalam falah

\begin{tabular}{|c|c|c|}
\hline Unsur Falah & Aspek Mikro & Aspek Makro \\
\hline \multirow[t]{4}{*}{ Kelangsungan Hidup } & 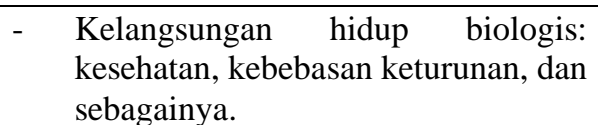 & $\begin{array}{ll}\text { Keseimbangan } & \text { ekologi } \\
\text { dan lingkungan } & \end{array}$ \\
\hline & $\begin{array}{l}\text { Kelangsungan hidup ekonomi: } \\
\text { Kepemilikan faktor produksi }\end{array}$ & $\begin{array}{ll}\text { - } & \text { Pengelolaan Sumber } \\
\text { Daya Alam } \\
\text { - } \\
\text { Penyediaan kesempatan } \\
\text { berusaha untuk semua } \\
\text { penduduk }\end{array}$ \\
\hline & $\begin{array}{l}\text { - } \quad \text { Kelangsungan hidup sosial: } \\
\text { Persaudaraan dan harmoni hubungan } \\
\text { sosial }\end{array}$ & $\begin{array}{l}\text { Kebersamaan sosial, } \\
\text { ketiadaan konflik } \\
\text { antarkelompok }\end{array}$ \\
\hline & $\begin{array}{ll}\text { - } & \text { Kelangsungan hidup politik: } \\
\text { Kebebasan dalam partisipasi politik }\end{array}$ & - $\quad$ Jati diri dan kemandirian \\
\hline \multirow[t]{2}{*}{ Kebebasan Berkeinginan } & - $\quad$ Terbebas kemiskinan & $\begin{array}{l}\text { - } \begin{array}{l}\text { Penyediaan Sumber } \\
\text { Daya untuk seluruh } \\
\text { penduduk }\end{array} \\
\end{array}$ \\
\hline & - $\quad$ Kemandirian hidup & $\begin{array}{l}\text { - Penyediaan Sumber Daya } \\
\text { untuk generasi yang akan } \\
\text { datang }\end{array}$ \\
\hline \multirow[t]{2}{*}{ Kekuatan dan Harga Diri } & - $\quad$ Harga diri & $\begin{array}{ll}\text { - } & \text { Kekuatan ekonomi dan } \\
\text { kebebasan dari utang }\end{array}$ \\
\hline & $\begin{array}{l}\text { Kemerdekaan, } \quad \text { perlindungan } \\
\text { terhadap hidup dan kehormatan }\end{array}$ & Kekuatan militer \\
\hline
\end{tabular}

Sumber: Akram Khan dalam Pusat Pengkajian dan Pengembangan Ekonomi Islam (2014: 3).

Dijelaskan dalam Q.S. Quraisy: 1-4 yang berbunyi:

"karena kebiasaan orang-orang Quraisy, (yaitu) kebiasaan mereka bepergian pada musim dingin dan musim panas. Maka hendaklah mereka menyembah Tuhan (pemilik) rumah ini (Ka'bah), yang telah memberi makanan kepada mereka untuk menghilangkan lapar dan mengamankan 
mereka dari rasa ketakukan". (Q.S. Quraisy: 1-4)

Ayat di atas menjelaskan bahawa Allah Swt. telah memberikan keberkahan kepada kaum Quraisy dengan dilimpahkannya sumber makanan untuk memenuhi kebutuhan hidup. Suku Quraisy dianugerahi oleh Allah Swt. beberapa kemuliaan (A1Faizin dan Nashr, 2018: 287). Mereka secara turun-temurun menjadi pengelola Ka'bah dan penguasa Mekkah (Az-Zuhaili, vol. 30, 1998: 414). Sama halnya pada seorang enterpreneur, Allah Swt. telah menyediakan sumber daya Alam yang dapat dikelola menggunakan upaya dan daya pikir yang telah dianugerahi-Nya.

Dalam sebuah hadish pula dijelaskan:

“sesungguhnya Nabi Muhammad Saw. ditanya mengenai pekerjaan yang paling baik. Beliau menjawab, "Pekerjaan yang paling baik adalah pekerjaan seorang laki-laki yang dilakukan dengan menggunakan jerih payah tangannya sendiri serta setiap jual-beli dengan cara yang baik." (HR.

Ahmad dan ath-Thabrani).

Keberhasilan (Falah) itu adalah sebuah proses dari jerih payah, ketekunan, dan kesungguhan dalam menjalani bisnis. Perlu disadari oleh seorang enterpreneur muda bahwa menuju sebuah kesuksesan memerlukan sebuah perjuangan keras serta ketekunan dalam menjalankan apa yang dicita-citakan.

\section{Upaya untuk Keberlangsungan UMKM di Masa Pandemi Covid-19 di Indonesia}

Wabah Covid-19 dapat secara signifikan berdampak pada ekonomi global dalam jangka pendek (McKibbin dan W. Fernando, 2020). lebih lanjut Baldwin dan B.W. Mauro (2020) menyatakan pada perkembangan Covid-19 selanjutnya, tidak hanya memberikan efek negatif bagi wilayah dan negara yang tertimpa Covid-19, tetapi berdampak lebih lanjut pada negara lain karena terkait dengan value chain economic. Indonesia diumumkan terdampak virus oleh Presiden Joko Widodo tanggal 2 Maret 2020. Badan Penanggulangan Bencana (BNBP) secara khusus menyebut Covid-19 bencana non alam (non natural disaster) dengan skala cakupan nasional. Seiring dengan hal tersebut, diawali dari DKI Jakarta sebagai ibu kota negara dan diikuti oleh daerah lainnya, Pembatasan Sosial Berskala Besar (PSBB) diberlakukan. Akibat dari PSBB tersebut, banyak terjadi Pemutusan Hubungan Kerja (PHK) di setiap perusahaan. oleh sebab itu, terjadi pengangguran besar-besaran di berbagai daerah. Banyak dari para pengangguran yang memutar otak untuk dapat menghasilkan pendapatan yaitu melalui berwirausaha. 
Dalam Hadiwardoyo (2020) Kunci dari penyehatan kembali kondisi ekonomi nasional adalah survival di tingkat individu dan entitas usaha, negara harus mengerahkan segenap upaya, termasuk dengan memberikan stimulus, agar rakyatnya tidak collaps semasa kisis sehingga yang diperlukan adalah kebijakan yang tepat, baik secara lokasi, waktu maupun prosedurnya. Taufik dan Eka (2020) juga menjelaskan bahwa bagi pengusahan UMKM, terutama usaha mikro dan kecil perlu memanfatkan momentum Covid-19 sebagai langkah menyesuaikan diri secara cepat dengan mengembangkan inovasi produk sesuai dengan kecenderungan permintaan pasar disertai penyesuaian $e$ commerce dan aplikasi online. Rohmah (2020) menjelaskan ada banyak peluang usaha di tengah-tengah terpuruknya perekonomian saat ini, baik peluang usaha yang berskala besar dan kecil seperti bisnis di bidang kesehatan, dan kebersihan lingkungan memiliki peluang yang sangat menjanjikan, begitu juga bisnis makanan beku dan minuman juga tidak kalah prospektif. Dalam penelitian Awali dan Farida (2020) dijelaskan kemajuan teknologi dan revolusi industri 4.0 sangatlah memiliki peranan penting bagi persaingan industri yang diiringi dengan diterapkannya revolusi intership, sehingga dengan memanfaatkan peluang seiring dengan perkembangan teknologi dan revolusi industri diharapkan pelaku usaha mampu memanfaatkan peluang serta memperbaiki tingkat perekonomian suatu negara di tengah pandemi Covid-19 yang sedang dihadapi dunia dan khususnya Indonesia.

\section{METODE}

Penelitian ini merupakan penelitian kualitatif deskriptif berbasis data sekunder dari referensi kepustakaan (penelitian terdahulu, buku, dan website resmi lembaga) terkait dengan kreativitas dan inovasi dalam Islam terhadap Keberlangsungan UMKM di masa Pandemi Covid-19 di Indonesia.

\section{HASIL DAN PEMBAHASAN}

Pengenalan Terhadap Lingkungan dalam Bisnis Usaha Mikro, Kecil, dan

\section{Menengah (UMKM)}

Sebelum sesorang mendirikan sebuah bisnis usaha, haruslah mengetahui dan mengenal lingkungan usahanya baik dalam lingkup mikro maupun makro. Lingkungan usaha tidak dapat diabaikan begitu saja karena akan berdampak langsung baik dapat menjadi pendorong ataupun penghambat jalannya perusahaan. Dalam lingkup sederhana, seorang pendiri bisnis usaha secara otomatis telah menjadi seorang pemimpin dalam bisnis usahanya. dari Gambar 1.1 di bawah menunjukkan dalam lingkup mikro, peran 
seorang pemimpin perusahaan adalah dapat mengarahkan dengan tepat karyawannya sesuai dengan jobdisk yang telah diberikan. tanpa seorang pembisnis yang memiliki jiwa kepemimpinan, maka produktifitas perusahaan akan mengalami kekacauan. Selanjutnya seorang pembisnis juga harus mengecek persediaan bahan baku yang nantinya akan diolah menjadi produk yang akan dijual, maka hubungan pembisnis dan pemasok adalah hal yang sangat diutamakan. Tanpa pemasok, suatu bisnis usaha tidak dapat memproduksi barang dan jasa yang akan dipasarkan.

Kemudian seorang pembisnis harus memiliki link atau hubungan kerjasama yang luas dengan pembisnis lainnya yang berperan sebagai penyalur atau dropsipper. Tanpa adanya penyalur tentunya sebuah bisnis usaha tidak akan dapat memasarkan suatu produk kepada pelanggan. Terakhir, selain adanya peran penyalur, seorang pembisnis juga dapat berperan dalam pemasaran produknya, seorang pembisnis harus dapat menarik minat konsumen agar tertarik dan membeli produknya dan dapat menjadi pelanggan setia.

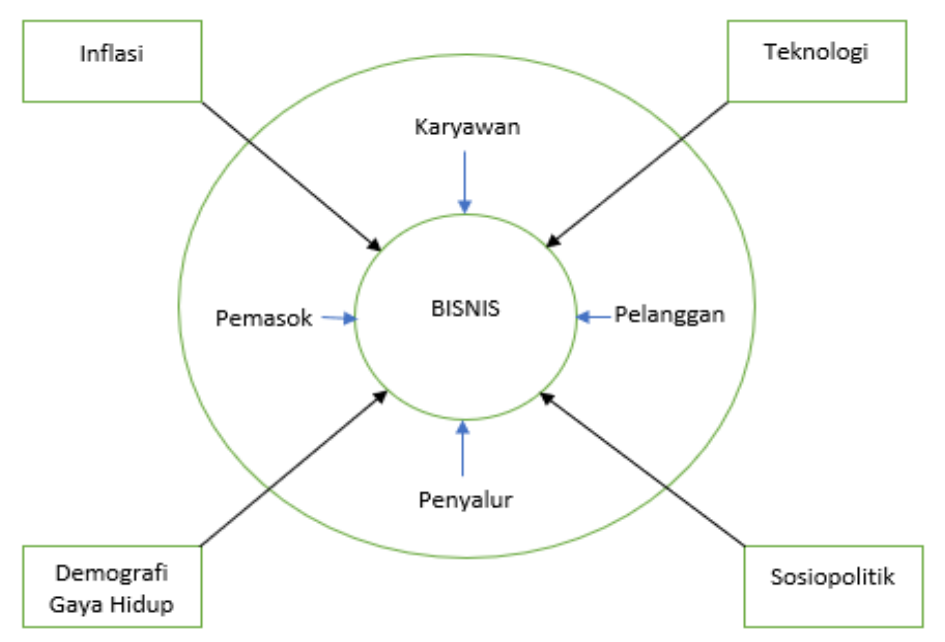

Gambar 1.1. Lingkungan Usaha

Sumber: (Suryana, 2013: 134).

Peran seorang pembisnis pada lingkungan makro yaitu terletak pada kemampuannya mengamati kondisi ekonomi yang saat ini terjadi dan mungkin dapat mempengaruhi pendapatan bisnisnya. Seorang pembisnis harus dapat melihat kebutuhan masyarakat yang didasari oleh gaya hidupnya saat ini, terutama di masa Pandemi Covid19 seperti kebutuhan akan masker, faceshield, handsanitaizer, dan konsumsi makanan yang dapat meningkatkan imunitas tubuh. Kemudian, seorang pembisnis harus sangat memahami peranan dari adanya teknologi seperti penggunaan android yang di dalamnya terdapat banyak platform marketplace pendukung dalam memasarkan produk, dan dapat 
diunduh secara gratis seperti Shopee, Lazada, BukaLapak, Tokopedia, dan platform marketplace lainnya.

Selanjutnya, seorang pembisnis harus dapat mengamati kondisi ekonomi yang tengah terjadi di masa Pandemi Covid-19 saat ini, beberapa bisnis usaha terutama di bidang kesehatan seperti suplemen makanan, masker dan handsanitaizer mengalami peningkatan permintaan, menyebabkan langkanya ketersediaan bahan baku sehingga harga-harga produk tersebut melonjak drastis. Terakhir pada lingkungan makro, seorang pembisnis juga harus dapat mengamati kondisi sosiopolitik yang saat ini terjadi di tengahtengah Pandemi Covid-19 salah satunya yaitu dampak sosiopolitik yang terjadi setelah disahkannya UU Cipta Kerja tahun 2020 di Indonesia baik dari sisi positif maupun negatifnya.

\section{Kreativitas dan Inovasi dalam Islam terhadap Keberlangsungan Sektor Usaha Mikro, Kecil, dan Menengah di Masa Pandemi Covid-19 di Indonesia}

Telah dijelaskan pada landasan teori, seorang pembisnis harus memiliki kreatifitas dan inovasi dalam menjalankan bisnis usahanya. karena kedua hal tersebut telah menjadi ruh bagi suatu bisnis usaha. Seorang pembisnis harus memiliki kiat-kiat agar kreatifitas dan inovasinya dapat terus muncul dan berkembang. Tanpa ada gagasan yang kreatif dan inovatif, usaha yang dilakukan oleh seorang enterpreneur akan ketinggalan karena konsumen selalu berubah dan selalu menuntut hal yang baru (Al-Faizin dan Nashr, 2018: 286). Ketahanan setiap lapisan atau tingkatan tersebut berbeda-beda, maka msyarakat ekonomi golongan menengah ke bawah khususnya mikro dan pekerja informal berpendapatan harian, tentu menjadi kelompok yang paling rentan terkena dampaknya (Aswar, www.kemenkeu.go.id, 4 Mei 2020). Bagi seorang pelaku ekonomi di sektor UMKM, kreativitas dan inovasi memang sangat dibutuhkan. Untuk dapat mengambangkan kedua aspek utama tersebut, Seorang pelaku UMKM harus memiliki kiat-kiat agar dapat bertahan dan mampu bersaing di tengah-tengah pandemi Covid-19. Beberapa kiat-kiat tersebut diantaranya di bawah ini.

- Pertama, memiliki kepercayaan diri dan kemandirian yang tinggi. Dari kedua sikap tersebut berkaitan dengan seorang pengusaha harus berani mengabil risiko dan yakin bahwa usahanya akan berhasil. Seseorang yang memiliki kepercayaan diri cenderung memiliki keyakinan akan kemampuan untuk mencapai keberhasilan (Zimmerer, 1996: 7-dalam suryana). Risiko harus kita hadapi dan 
kita kelola dengan baik, karena di balik risiko yang besar akan ada sebuah peluang dan keuntungan yang besar pula atau disebut dengan high risk haigh return (AlFaizin dan Nashr, 2018: 286-287). Karena seorang enterpreneur harus mampu memandang risiko sebagai peluang usaha, maka pelaku UMKM harus dapat melihat aspek yang terdapat dalam sebuah peluang. Hal tersebut digambarkan dalam analisis dampak silang (cross-impact analysis) yang dikemukakan oleh Zimmerer dalam (Suryana, 2013: 137).

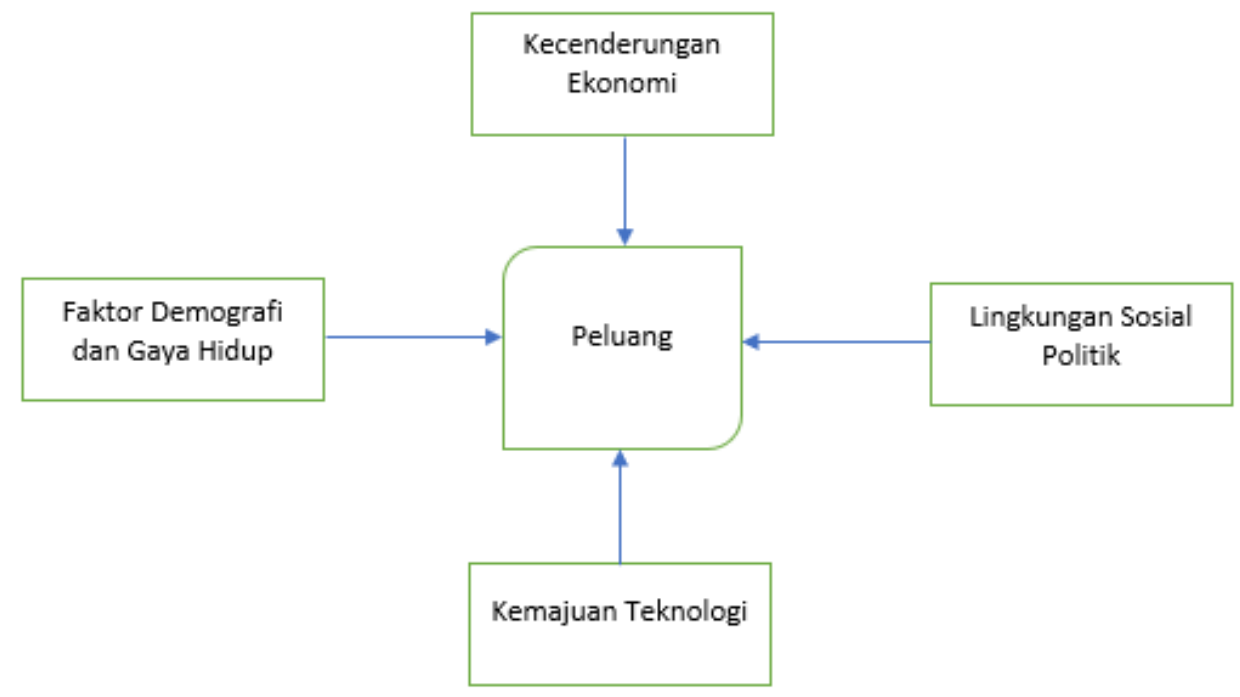

\section{Gambar 1.2. Cross-impact Analysis}

Sumber: Thomas Zimmerer dalam Suryana (2013: 137).

Pada Gambar 1.2. di atas, peluang lebih melihat pada kondisi makro yang terjadi di Indonesia saat ini (penjelasan pada Gambar 1.1), dari ke empat kondisi makro di atas, semuanya memiliki keterkaitan satu sama lain. Adanya permintaan produk terjadi karena adanya gaya hidup yang dijalani konsumen. Percepatan teknologi yang memberikan manfaat dalam memperoleh informasi, memudahkan konsumen dalam mendapatkan produk kebutuhannya, menyebabkan permintaan akan suatu barang mengalami peningkatan. Lingkungan sosial yang mempengaruhi gaya hidup seseorang seperti mengonsumsi makanan cepat saji memberikan kepraktisan dan kebijakan pemerintah sebagai regulasi yang memberikan legalitas dalam memperjual-belikan suatu barang dan jasa memberikan percepatan dalam penawaran dan permintaan. Dalam menghasilkan suatu produk tentunya seorang pengusaha harus melihat seberapa besar permintaan atas barang tersebut di pasaran. Hal ini akan mempengaruhi 
kebutuhan bahan baku dalam memproduksi (ketika permintaan naik maka bahan baku yang dibutuhkan akan meningkat dan permintaan yang tinggi menyebabkan kelangkaan bahan baku) sehingga biaya bahan baku akan meningkat. Kecenderungan ekonomi seperti ini disebut dengan inflasi. Inflasi dapat dianggap sebagai fenomena moneter karena terjadinya penurunan nilai unit penghitungan moneter terhadap suatu komoditas (Karim, 2015: 135).

- Kedua, berbisnis yang halal, mulai dari modal, proses, hingga penjualan. Islam mengajarkan agar manusia menjalani kehidupannya secara benar sebagaiamana telah diatur oleh Allah, bahkan, usaha untuk hidup secara benar dan menjalani hidup secara benar inilah yang menjadikan hidup seseorang bernilai tinggi (Pusat Pengkajian dan Pengembangan Ekonomi Islam, 2014: 6). Bisnis yang benar didominasi oleh maksud dan tujuan yaitu: 1) untuk mencari ridla Allah (Mardlatillah); 2) keinginan memperoleh kesejahteraan dari Allah; 3) mencari rahmat Allah; 4) berniat mencari dan memperoleh pahala dari Allah; 5) bisnis yang dilakukan berkonotasi dengan persiapan kehidupan di akhirat; 6) bermanfaat bagi kemaslahatan umat manusia; 7) memproduksi barang dan jasa yang dibutuhkan bagi kehidupan manusia; dan 8) mendatangkan berkah dan rizki bagi semua pihak. Sehingga dari beberapa tujuan tersebut akan mengarahkan seorang pembisnis pada cakupan bisnis yang halal secara keseluruhan. Dijelaskan dalam Q.S. at-Taubah: 72 yang berbunyi:

“Allah menjanjikan kepada orang-orang yang mu'min lelaki dan perempuan, (akan mendapat) syurga yang di bawahnya mengalir sungai-sungai, kekal mereka di dalamnya, dan (mendapat) tempattempat yang bagus di syurga 'Adn. Dan keridlaan Allah adallah lebih besar; itu adalah keberuntungan yang besar”.(Q.S. at-Taubah: 72)

Dan pada Q.S. Fatir: 29-30 yang berbunyi:

"Sesungguhnya rang-orang yang selalu membaca kitab Allah dan mendirikan shalat dan menafkahkan sebagian dari rizki yang Kami anugerahkan kepada mereka dengan diam-diam dn terang-terangan, mereka itu mengharapkan perniagaan yang tidak akan merugi, agar Allah menyempurnakan kepada mereka pahala mereka pahala mereka dan menambah kepada mereka dari karunia-Nya. Sesungguhnya Allah 
Maha Pengampun lagi Maha Mensyukuri”.(Q.S. Fatir: 29-30)

Jika motivasi ingin mendapat ridla Allah dalam melakukan bisnis maka dapat dipastikan bahwa bisnis yang dilakukan merupakan investasi yang terbaik dan hal ini dilakukan dengan harapan mendatangkan kesenangan, kebahagiaan, dan kesejahteraan lahiriah dan batiniah bagi umat manusia yang lain maka diyakini kebenarannya sesuai dengan aqidah Islam.

- Ketiga, melakukan ekspor dan impor barang. Dalam hal ini seorang pembisnis harus memiliki pangsa pasar yang luas. Di jaman yang serba daring ini, pemasaran terhadap suatu produk lebih mudah dilakukan. Terlebih hal tersebut karena adanya sosial media dan platform marketplace yang memberikan manfaat terhadap kemudahan informasi kepada konsumen baik dari dalam maupun luar negeri. Dengan demikian, pangsa pasar seorang pembisnis akan lebih luas. Ekspor produk sangat perlu dilakukan oleh seorang pembisnis karena akan meningkatkan pendapatan, dan seorang pembisnis juga harus melakukan impor baik bahan baku maupun produk yang akan dipasarkan kembali, hal ini bertujuan untuk meningkatkan nilai jual pada produk yang ditawarkan.

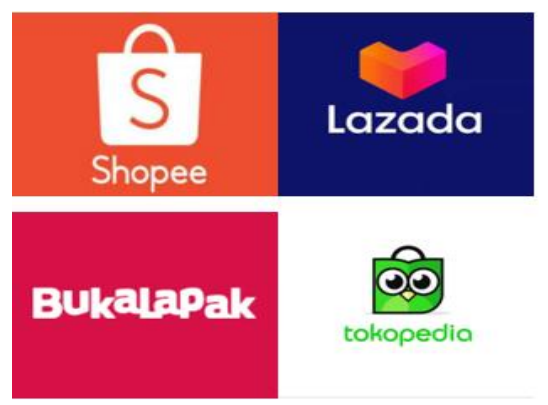

\section{Gambar 1.3. Beberapa Platform Marketplace yang ada di Indonesia}

Sumber: www.google.co.id diunduh 3 Desember 2020.

- Keempat, harus bisa menjaga kepercayaan relasi bisnis. Dalam konteks social capital, Piotr Sztompka dalam Al-Faizin dan Nashr (2018: 201) dan mengartikannya dengan sebuah bentuk keinginan untuk mengambil risiko dalam hubungan-hubungan sosialnya yang didasari oleh perasaan percaya dan yakin bahwa yang lain akan melakukan sesuatu seperti yang diharapkan dan akan senantiasa bertindak dalam suatu pola tindakan yang saling mendukung. Dalam suatu hadish, diriwayatkan Rasulullah saw. bersabda: 
“Berbaik sangka termasuk ibadah yang baik”.(HR Ahmad dan Ibnu

Hibban)

dari hadish di atas dijelaskan bahwa dalam menjaga kepercayaan relasi bisnis harus dilandasi oleh prasangka yang baik, maka seorang pembisnis akan berfikir bahwa relasi akan berprasangka baik pula, sehingga hal tersebut akan membangun diri untuk tetap menjaga kepercayaan relasi bisnis.

Mengingat relasi seorang pembisnis UMKM adalah perusahaan jasa yang memiliki kemitraan pada bisnis usaha yang dijalankan, maka hal yang harus dilakukan adalah menjaga komitmen dalam jual-beli bersama-sama. Ketika konsumen yang melakukan order melalui platform kemitraan maka pelaku UMKM harus menyampaikan informasi terkait produk yang sedang ready ataupun tidak secara up-to-date, dan apabila dalam proses penanganan produk untuk segera dikirimkan, maka pelaku UMKM harus mengiformasikan kepada mitra kerja agar segera disampaikan kepada konsumen yang sedang menunggu. Hal ini dilakukan agar konsumen tidak mengambil tindakan pembatalan yang mengakibatkan kerugian kepada pihak mitra kerja.

- Kelima, melakukan promosi barang yang diperdagangkan, yaitu dengan membuat iklan baik di media elektronik maupu media cetak. Seorang pembisnis selain melakukan promosi melalui brosur atau spanduk, harus juga melakukan pemasangan iklan melalui platform aplikasi sosial media seperti Instagram dan Facebook, atau platform marketplace seperti Shopee, Lazada, BukaLapak, dan Tokopedia, serta platform pencarian informasi seperti Google karena hal ini dapat mempercepat dan memudahkan pelaku usaha dalam mempromosikan produknya. Teknologi dari e-marketing mampu merubah banyak strategi pemasaran, hasil perubahan dalam model bisnis baru ini mampu menambah nilai (value) pelanggan dan meningkatkan keuntungan perusahaan. E-marketing dengan memanfaatkan teknologi melalui jaringan dapat mengkoordinasi penelitian pangsa pasar, membantu pengembangan produk, mengembangkan strategi dan taktik untuk menarik pelanggan, menyediakan distribusi online, mempertahankan catatan pelanggan, menciptakan kepuasan pelanggan, dan mengumpulkan umpan balik pelanggan (Awali dan Farida, 2020). Selain itu, promosi dapat lebih menarik konsumen dengan memberikan taster dan diskon harga pada awal launching 
produk (Rohmah, 2020). Strauss dan Frost dalam Awali dan Farida (2020) menjelaskan terdapat tujuh tahap dalam perancangan $e$-marketing yang dijelaskan pada Tabel 1.2 di bawah ini.

Tabel 2

Tahapan pelaksanaan $e$-marketing

\begin{tabular}{|c|c|c|}
\hline No. & Tahapan E-Marketing & Konsep \\
\hline 1. & Analisis Situasi & Strengths, opportunities, weakness, and threats \\
\hline 2. & $\begin{array}{l}\text { Perencanaan Strategi } E \text { - } \\
\text { marketing }\end{array}$ & Market opportunity analysis \\
\hline 3. & Objectives & Tugas, kuantitas, dan time frame \\
\hline 4. & Strategi E-marketing & Relationship management (product, price, plaece and promotion) \\
\hline 5. & Rencana Pelaksanaan & $\begin{array}{l}\text { Pada tahap ini perusahaan memutuskan bagaimana untuk } \\
\text { mencapai tujuan melalui strategi yang efektif dan kreatif. Pemasar } \\
\text { memilih bauran pemasaran (4P), strategi manajemen dan strategi } \\
\text { lain untuk mencapai tujuan rencana dan kemudian menyusun } \\
\text { rencana pelaksanaan (Implementation Plan). Perusahaan juga } \\
\text { memeriksa untuk memastikan organisasi pemasaran yang tepat di } \\
\text { tempat pelaksanaan (staf, struktur departemen, penyedia layanan } \\
\text { aplikasi, dan lain-lain di luar perusahaan). internet telah mengubah } \\
\text { tempat pertukaran dari marketplace (seperti interaksi face-to-face) } \\
\text { menjadi marketspace (seperti interaksi screen-to-face). Perbedaan } \\
\text { utama adalah bahwa sifat hubungan pertukara sekarang ditengahi } \\
\text { oleh interface teknologi. Dengan perpindahan dari hubungan } \\
\text { antarmuka people-mediated menjadi technology-mediated, } \\
\text { terdapat sejumlah pertimbangan perancangan interface yang } \\
\text { dihadapi. }\end{array}$ \\
\hline
\end{tabular}

6. Budget Internet adalah tools yang mampu digunakan untuk melihat hasil dari catatan teknologi dari setiap klik. Tujuannya adalah untuk mendapatkan informasi anggaran yang dapat dipertanggungjawabkan, maka perlu dibuat perhitungan tentang revenue forecast (perkiraan pendapatan), intangible benefits (manfaat tidak berwujud), cost savings ((penghematan biaya), dan e-marketing cost (biaya e-marketing).

7. Evaluation Plan Perencanaan e-marketing dilaksanakan, keberhasilannya
bergantung dari evaluasi yang dilakukan secara terus-menerus. Jenis evaluasi ini tergantung pada tujuan rencana. Untuk menentukan hasil pemasarannya, perusahaan dapat menggunakan balanced scorecard untuk mengukur kesuksesan dari suatu 


\begin{tabular}{lll}
\hline No. Tahapan E-Marketing & \multicolumn{3}{c}{ Konsep } \\
\hline & program internet marketing dan apakah program internet \\
& marketing tersebut cocok dan sesuai dengan objektif dari \\
& perusahaan.
\end{tabular}

Sumber: Strauss dan Frost dalam Awali dan Farida (2020) telah diolah.

- Keenam, berbisnis barang kebutuhan dasar. Di masa pandemi covid-19 saat ini, kebutuhan dasar masyarakat akan lebih dipengaruhi oleh situasi dan kondisi yang ada, kebiasaan masyarakat berubah menyebabkan kebutuhan hidupnya akan berubah pula. Kebutuhan dasar akan cenderung melihat manfaat yang diperoleh pada masa seperti saat ini agar terhindar dari penyakit terutama covid-19. Oleh karenanya, objek yang dikonsumsi harus diperhatikan kemanfaatannya bagi diri sendiri dan juga bagi orang lain (Al-Faizin dan Nashr, 2018: 274).

Dalam Q.S. al-Maidah: 87-88 dijelaskan bahwa:

“Wahai orang-orang yang beriman!Janganlah kamu mengharamkan apa yang baik yang dihalalkan Allah kepadamu, dan janganlah kamu melampaui batas. Sesungguhnya Allah tidak menyukai orang-orang yang melampaui batas. Dan makanlah dari apa yang telah diberikan Allah kepadamu sebagai rezeki yang halal dan baik, dan bertakwalah kepada Allah yang kamu beriman kepada-Nya”. (Q.S. al-Maidah: 87-

Dari ayat di atas dimaksudkan agar seorang Muslim hendaknya memperhatikan apa yang halal dan apa yang haram untuk dikonsumsi. Memperhatikan kemanfaatan dari sesuatu yang dikonsumsi akan memberikan kebaikan bagi kesehatan jasmani dan rohani.

Beberapa kebutuhan dasar yang akan paling dicari oleh konsumen meliputi kebutuhan pangan, suplemen untuk kesehatan tubuh, jamu, dan perlengkapan tambahan untuk menjaga kontak langsung dengan yang lainnya seperti handsanitaizer dan masker. Seperti berbisnis makanan dalam kemasan yang dijual secara online dan dapat dilakukan pelayanan pesan antar melalui kemitraan bersama dengan perusahaan jasa antar yang bisa dipesan oleh konsumen melalui platform aplikasi jarak dekat seperti yang telah dilakukan Grab dan Gojek, serta paltform pengiriman barang jarak jauh seperti J\&T, dan JNE. Hal tersebut akan lebih menguntungkan mengingat kebijakan social distancing 
melarang konsumen untuk membeli langsung dan memesan di tempat karena dapat menimbulkan kerumunan. Selain itu penjualan terhadap barang lainnya, yaitu suplemen kesehatan, jam, handsanitaizer, dan masker juga lebih cepat mendapatkan keuntungan.

- Ketujuh, adanya kepemimpinan yang baik dalam sebuah bisnis. Seseorang pembisnis yang berhasil selalu memiliki sifat kepemimpinan, kepeloporan, keteladanan, selalu ingin tampil berbeda, menjadi yang pertama, dan lebih menonjol dengan menggunakan kemampuan kreatif dan inovasi (Suryana, 2013: 42). Kepemimpinana tersebut memberikan seseorang untuk memiliki kebebasan dalam berinovasi dan berkreasi menciptakan sebuah produk barang maupun jasa. dijelasakan pada asas kebebasan dalam Islam. kebebasan dapat digunakan apabila tidak bertentangan dengan syariat Islam sebagaimana firman Allah SWT. dalam Q.S. al-Ma'idah ayat 1 yang berbunyi:

"Hai orang-orang yang beriman, penuhilah akad-akad itu. dihalalkan bagimu binatang ternak, kecuali yang akan dibacakan kepadamu. (yang demikian itu) dengan tidak menghalalkan berburu ketika kamu sedang mengerjakan haji. Sesungguhnya Allah menetapkan hukumhukum menurut yang dikehendaki-Nya”.(Q.S. al-Ma'idah: 1)

Kebebasan dalam jual-beli juga menjadi landasan bagi seorang pembisnis dalam berkreasi dan berinovasi yang dijelaskan dalam Q.S. an-Nisa': 29:

"Hai orang-orang yang beriman, janganlah kamu saling memakan harta sesamamu dengan jalan yang batil, kecuali dengan jalan perniagaan yang berlaku dengan suka sama suka di antara kamu. Dan janganlah kamu membunuh dirimu; sesungguhnya Allah adalah Maha Penyayang kepadamu”.(Q.S. an-Nisa': 29)

Sabda Rasulullah tentang hal ini disebutkan yang artinya: “Apa-apa yang dihalalkan Allah asalah halal dan apa-apa yang diharamkan Allah adalah haram dan apa-apa yang didiamkan dimaafkan. Maka, terimalah dari Allah pemaafan-Nya. Sungguh Allah itu tidak melakukan sesuatu pun”.(HR. al-Bazar dan at-Thabrani)

Sebagaimana seharusnya seorang pembisnis selalu mengutamakan batasan-batasan dalam berkreasi dan berinofasi, tidak melakukan sesuatu yang 
melanggar hukum dan aturan yang berlaku baik regulasi yag ditetapkan pemerintah maupun syariah (hukum Islam). selain itu kepemimpinan yang berpegang pada kreatifitas dan inovasi lebih kepada kebebasan berkeinginan dari aspek mikro maupum makro dalam mencapai falah (pada Tabel 1.1).

- Kedelapan, menggunakan teknologi informasi dalam berbisnis. Dengan adanya teknologi informasi diharapkan seorang pembisnis dapat mengetahui dan menganalisis pasar secara up-to-date terkait permintaan konsumen terhadap suatu produk barang dan jasa yaitu mengetahui produk barang dan jasa apa saja yang menunjang gaya hidup konsumen di masa seperti ini. Teknologi informasi lebih didominasi oleh sosial media seperti Instagram, dan Facebook, di kedua platform sosial media inilah banyak para pembuka lapak UMKM melakukan promosi terhadap produknya. Selain itu, seorang pembisnis juga harus melihat review dan penilaian terhadap penjualan suatu produk pada platform marketplace seperti Shopee, Lazada, Tokopedia, BukaLapak, dan lainnya.

Dari ke delapan kiat-kiat dalam berwirausaha di atas, diharapkan akan mampu memotivasi para pembisnis dan pemula yang masih baru memulai bisnis untuk tetap semangat dalam berkreasi dan berinovasi dalam menghasilkan produk, dan diharapkan juga dapat memberikan gambaran bagi seseorang agar menemukan jalan keluar untuk tetap memperoleh pendapatan di situasi pandemi Covid-19 seperti saat ini. Bagi pengusaha UMKM, terutama usaha mikro dan kecil perlu memanfaatkan momentum Covid-19 sebagai langkah menyesuaikan diri secara cepat dengan mengembangkan inovasi produk sesuai dengan kecenderungan permintaan pasar desertai penyesuaian $e$ comerce dan aplikasi online (Taufik dan Eka, 2020). Berbagai peluang usaha apabila ditekuni bisa mengurangi pengangguran, karena banyak menyerap tenaga kerja (Rohmah, 2020). Penggunaan e-marketing melalui marketplace dianggap perlu untuk diterapkan apalagi ditengah pandemi Covid-19 yang memberi dampak lemahnya perekonomian di seluruh sektor dan khususnya sektor industri, hal tersebut bisa menjamin keberlangsungan usaha UMKM dikarenakan sesuai dengan konsep revolusi 4.0 (Awali dan Farida, 2020). Apabila seluruh individu, entitas usaha, organisasi-organisasi nonbisnis, dan semua bagian dari seluruh negara dapat melewati masa krisis, tetap survive dan kembali berproduksi, makapada akhirnya kerugian nasional akan tertutupi (Hadiwardoyo, 2020). 


\section{SIMPULAN}

Dalam Islam, kreativitas dan inovasi juga berkaitan dengan ketakwaaan pada setiap individu sebaga pelaku ekonomi, mengarahkan pada aktivitas ekonomi yang positif. Sebelum sesorang mendirikan sebuah bisnis usaha, haruslah mengetahui dan mengenal lingkungan usahanya baik dalam lingkup mikro maupun makro. Beberapa kiatkiat tersebut diantaranya:

1. Memiliki kepercayaan diri dan kemandirian yang tinggi.

2. Berbisnis yang halal, mulai dari modal, proses, hingga penjualan,

3. Melakukan ekspor dan impor barang,

4. Harus bisa menjaga kepercayaan relasi bisnis,

5. Melakukan promosi barang yang diperdagangkan,

6. Berbisnis barang kebutuhan dasar,

7. Adanya kepemimpinan yang baik dalam sebuah bisnis,

8. Menggunakan teknologi informasi dalam berbisnis.

Dari ke delapan kiat-kiat dalam berwirausaha di atas, diharapkan akan mampu memotivasi para pembisnis dan pemula yang masih baru memulai bisnis untuk tetap semangat dalam berkreasi dan berinovasi dalam menghasilkan produk. Penggunaan $e$ marketing melalui marketplace dianggap perlu untuk diterapkan apalagi ditengah pandemi Covid-19 yang memberi dampak lemahnya perekonomian di seluruh sektor dan khususnya sektor industri.

\section{DAFTAR PUSTAKA}

Al-Faizin, Abdul Wahid dan Nashr Akbar, 2018. Tafsir Ekonomi Kontemporer: Menggali Teori dari Ayat-Ayat Al-Qur'an. Jakarta: Gema Insani.

Astamaoen, Moko P., 2005. Enterpreneur dalam Perspektif Kondisi Bangsa Indonesia. Bandung: Alfabeta.

Aswar, Solusi Ekonomi dan Keuangan IslamSaat Pandemi, www.kemenkeu.go.id, 4 Mei 2020.

Awali, Husni dan Farida Rohmah, 2020. Urgensi Pemanfaatan E-Marketing pada Keberlangsungan UMKM di Kota Pekalongan di Tengah Dampak Covid-19. Balance: Jurnal Ekonomi dan Bisnis Islam, Vol. 2, No. 1.

Az-Zuhaili, 1998. Tafsir al-Munir fi al-Aqidah wa asy-Syari'ah wa al-Manhaj. Vol. 30. Beirut: Darul Fikr.

Baldwin, R. dan B. W. Mauro, 2020. Economics in the Time of Covid-19. CEPR Press 


\section{VoxEU.org.}

Darsono, dkk., 2018. Memberdayakan Keuangan Mikro Syariah Indonesia: Peluang dan Tantangan ke Depan. Jakarta: Tazkia Publishing.

Hadiwardoyo, Wibowo, 2020. Kerugian Ekonomi Nasional Akibat Pandemi Covid-19. Baskara: Journal of Business \& Enterpreneurship, Vol. 2, No. 2.

Helmalia dan Afrinawati, 2018. Pengaruh E-Commerce terhadap Peningkatan endapatan

Usaha Mikro Kecil dan Menengah di Kota Padang. Jurnal Ekonomi dan Bisnis Islam, Vol. 3, No. 2.

Hendro dan Chandra, 2006. Be a Smart and Good Enterpreneur. Bekasi: CLA Publishing. Karim, A. Adiwarman, 2015. Ekonomi Makro Islami. Edisi ketiga. Jakarta: Rajawi Pers. McKibbin dan W. Fernando R., 2020. The Global Macroeconomic Impacts of Covid-19: Seven Scenarios. CAMA: Centre for Applied Macroeconomic Analysis, P 1-43.

Pusat Pengkajian dan Pengembangan Ekonomi Islam (P3EI), 2014. Ekonomi Islam. Jakarta: Rajawali Pers.

Rohmah, Siti Ngainnur, 2020. Adakah Peluang Bisnis di Tengah Kelesuan Perekonomian Akibat Pandemi Coronavirus Covid-19?. Adalah: Buletin Hukum \& Keadilan, Vol. 4, No.1.

Suryana, 2013. Kewirausahaan: Kiat dan Proses Menuju Sukses. Jakarta: Salemba Empat.

Taufik, dan Eka Avianti Ayuningtyas, 2020. Dampak Pandemi Covid-19 terhadap Bisnis dan Eksistensi Platform Online. Jurnal Pengembangan Wiraswasta, Vol. 22, No. 01. www.google.co.id, diunduh 3 Desember 2020.

Zimmerer, T.W., dan N.M. Scarborough, 1996. Enterprneurship and The New Venture Formation. New Jersey: Prentice Hall International Inc. 